otherwise alter until the field quickly became dark owing to the fusion of the crystal. This secms to indicate that the change in structure begins quite independently of the formation of the reflective layers, the latter being only an incident occurring at a particular stage of the cooling.

(6) It would seem that something of the following kind happens to the crystal. It is, of course, anisotropic in structure, and the effect of heat is to set up a molecular strain which at a certain point of temperature causes so strong a shearing action between nearly contiguous lajers of the substance that whole rows of crystal elements lying between these layers are rolled over, as it were, by the "couple" applied to them, until they take up their "sec snd positions of equilibrium," as M. Mallard would say (see his paper "Sur la Théorie des Macles," Bull. Soc. Min., December 1885, p. 467). If these latter positions were such as to bring the obtuse bisectrices (supplementary lines) into parallelism with a normal to the main plate, the occurrence of the hyperbolas abuve described would be fully accounted for. Such an action would be of the same general character as that which takes place in calc-spar when macles are being developed in it by Reusch's method ; viz. by carefully compressing a crystal of it in a definite direction (Pogg. Ann., vol. cxxxii. p. 445), I have succeeded by properly regulating the direction and amount of the pressure in making spar-macles containing numerous "planes of sliding" (Gleitflächen, as Prof. Reusch calls them), which reflect light with a pearly lustre, and almost as brightly as the potassium chlorate macles described above.

It has yet to be explained, however, why the intense reflective power does not show itself cluring the process of heating, when the tilting over of the crystals would certainly take place, and not until a particular stage of the cooling is reached. I am inclined to believe that this may be due to the substance acquiring a certain amount of plasticity at high temperatures, such as has been observed by M. Mallard in crystals of nitre under similar circumstances. This may prevent any loss of optical continuity until a certain critical point in the cooling has been reached; and at this point the displaced crystal elements suddenly part company with their unaltered neighbours, leaving a numerous series of parallel tubular cavities, precisely like those which are undoubtedly present in calc-spar macles formed by Reusch's method. The opposite sides of these parallelogrammatic cavities may be so near each other that the rays reflected from them may interfere, and give the colours of thin plates corresponding to a rather high order in Newton's scale. Although a large amount of light must escape reflection at any single cavity, yet if the transmitted rays encountered a large number of precisely similar and similarly situated cavities at slightly lower levels in the crystal, the sum of the partial reflections would produce an effect almost equivalent to a total reflection of the original incident ray, and a corresponding deficiency in the amount of light transmitted through the whole plate. The brilliancy of the colours in the light reflected from the well-known films of decomposed glass is accounted for in precisely the same way, and the successive separate films of glass can be easily seen under a microscope at the edges of the compound film, where they only partially overlap.

The fact that no brilliant reflection is observed in and near the plane of symmetry of the crystal may be due to the sides of the cavities in a given horizontal row not lying strictly in the same plane, but being slightly inclined alternately in opposite directions, so as to form a series of anticlinals and synclinals, or ridges and furrows like those of a roof. Thus a beam of light incident in the plane of symmetry would be reflected in directions lying a little to the right and left of this plane, and not in the plane itself. The satin-like appearance of the reflecting layers, already alluded to, would be fully accounted for by such a structure.

The changes above described seem of interest as bearing upon the cause of the strong iridescence of some crystals of potassium chlorate, about which I may have something to say in a future communication.

Eton College, May ro

\section{SCIENCE IN RUSSIA}

THE last volume of the Memoirs of the Kharkoff Society of Naturalists (vol. xviii.) contains several papers of interest. All who have had to deal with Acarides, and are acquainted with the difficulties of their classification, will welcome the elaborate memoir, by M. Krendowsky, on the Hydrachnids of
Southern Russia. It is not a mere description of forms, with a more or less happy classification, but an elaborate contribution towards the systematic arrangement of this imperfectly-known subdivision. The embryogeny of the Hydrachnids, and especially their larval phase, have received special attention, no satisfactory classification being possible without that preliminary study. It appears also from M. Krendowsky's researches that many Hydrachnids of Southern Russia are really temporary parasites on several insects, mollusks, and sponges, especially when young and in the state of six-footed larvæ. The Hydrachnids of South-Western Kussia belong to thirty-five species (nine species each of Nesaa and Arrenurus, five of Atax, and four of Limnesia); the author has been led to revise the whole of the classification of the freshwater Acarides, and gives it complete, with analyses of each family, as well as of the very numerous genera.

Another paper of great interest is devoted by the same author to the estuaries of the Bug, Dnieper, and the smaller ones in the neighbourhoods of Kherson and Odessa. This paper is full of the most useful information as to the characters and geological history both of these estuaries and the limans, which are now shut off from the sea by their sand-bars, and have become mere elongated salt lakes.

Prof. Lewakowsky contributes to the same volume a paper on the Jurassic limestones of the Crimea, based especially on their micro-structure. It appears that they mostly contain very small debris of cor:ls and rhizopods; they are not coral structures, as was supposed, but have much likeness to what Dana describes as beachsand-rock. Like the clay-slates of the same formation in the Crimea, they have been deposited in a wide basin which extended into Kherson and Ekaterinoslav, and they were composed of materials brought from the south, from a continent which occupied part of what is now sulmmerged by the Black Sea. M. Genjouriste's researches into the microscopical structure of the coal of the Donez Basin are interesting inasmuch as they show that the prevailing materials for the formation of this coal were the higher vascular Cryptogams, and not Algæ, as was sometimes supposed by Kussian geologists. Dr. M. Dybowsky's additional note on the Spongilla Dorvilia stepanovii, one of the most interesting discovered in Europe, contains a description of the structure of its gemmulæ, with the porous and "cirrous appendages." The note, as also the preceding papers, are accompanied by several plates.

\section{SCIENTIFIC SERIALS}

The Quarterly Fournal of Microscopical Science, vol. xxvi, part 3, April 1886, contains a memoir on the leeches of Japan, by Dr. C. O. Whitman (plates I7 to 2I). A short abstract of this important memoir has been given in our Biological Notes. -Contributions to the embryology of the Nemertea, by Prof. A. A. W. Hubrecht (plate 22). No. I is an account of the development of Lineus obscurus, Barr. These investigations, already published in the Dutch language, are fully detailed in this paper, and the plate gives the details of the principal results, combined into fifteen diagrammatic tracings. In one section the earliest developmental stages and the derivatives of the primary epiblast; in a second the hypoblast before the shedding of the primary larval integuments; and in a third the mesoblast, are treated of. - On the early development of Julus terrestris, by F. G. Heathcote, M.A. (plates 23 and 24). This is the first part of an essay on a subject not treated of by British naturalists since the days of Newport. It treats of the segmentation of the ovum, which shows a remarkable resemblance to that found in Amphipods by Uljanin. The formation of the blastoderm is such as is generally found in tracheate development. The cells, which at the conclusion of the blastoderm formation remain within the yolk, represent the endoderm. The mode of formation of the mesoderm almost exactly resembles that described by Balfour for spiders. In a future paper the author intends describing the further developmental stages of the embryo.William A. Haswell, M.A., on the structure of the so called glandular ventricle (Drïsenmagen) of Syllis (plate 25). This organ is in reality a well-developed muscular gizzard, and contains no glands in its walls. The muscular elements of the organ present an embryonic character containing as they do a polynucleated. core.-Arthur B. Lee, on Carnoy's cell researches (plate 26). While Carnoy's conceptions of the cell body do not materially differ from received views, the author of this paper thinks that sufficient attention has not been given to his labours on the 
question.-Prof. E. Ray Lankester, the Pleomorphism of the Schizophyta. A reminder of the simple fact that ten years ago Prof. Lankester called attention to the pleomorphism of the Schizophyta in a paper in this Fournal, which attracted the deep attention of all those botanists who had taken any interest in the subject.

Fournal of Anatomy and Physiology, April r886, vol. xx., part 3, contains :-Dr. J. W. Frazer, on the action of infused beverages on peptic digestion. This paper is a continuation of one in the eighteenth volume of this fournal, and is based on the results of the same experiments, the difference being that the amount of peptones dialysed, instead of being estimated as the total organic matter, as was done in that paper, are here esti nated by the amount of organic nitrogen.-W. A. Lane, some variations in the human skeleton; asymmetry of skull, spinal column, \&c., bifid ribs.-Dr. R. L. MacDonnell, case of bicipital rib.-Dr. R. W. Shufeldt, osteology of Conurus carolinensis (plates 10 and $\mathrm{I}$ ). The extermination of this parrot appears imminent. To this memoir there is appended a synopsis of the skeletal characters of this bird which exhibit many pints of interest.-On a Navajo skull (plate I2), with a note by Sir Wm. Turner.-J. Bland Sutton, on the origin of certain cysts (plate I3).-Dr. J. Lockhart Gibson, the blood-forming organs and blood-formation : an experimental research (plate 14) (continued). Among the chief conclusions are the following: throughout life, nucleated red cells, derived from white corpuscles and colourless marrow-cells, are the only predecessors of the nonnucleated red blood-corpuccles. The transformation takes place in the bone marrow, spleen, and lymphatic glands; the red bone marrow in extra-uterine life plays the more important part in the work, the spleen a subordinate one ; the lymphatics, while chiefly producing white, do also produce red corpuscles. Both colourless cells and nucleated red cells multiply by division in the blood-forming organs, and in these latter there are also to be found cells whose function appears to be to break down red blood-corpuscles.-Dr. E. E. Maddox, on the relation between convergence and accommodation of the eyes.-Dr. R. Robertson, a contribution to splenic pathology (plate 15).- -Dr. F. Tuckerman, supernumerary leg in a male frog (Rana palustris) (plate 16).-Dr. D. Noël-Paton, the nature of the relationship between urea formation and bile secretion. Both these phenomena would seem to depend in large measure on the destruction of blood-corpuscles, and through this they necessarily bear a direct relationship to one another.-Prof. D'Arcy W. 'Thompson, on the hind limb in Ichthvosaurus platyodon, and on the morphology of vertebrate limbs. - Sir $\mathrm{Wm}$. Turner, on the lumbar curve of the spinal column in several races of men (see also abstract of a memoir on this subject by Prof. D. J. Cuningham, NATURE, vol. xxxiii. p. 378).-Anatomical notes.

American Fournal of Science, April.-On Lower Silurian fossils from a limestone of the original Taconic of Prof. Emmons, by James D. Dana. These fossils were recently found in the "sparry" or western limestone of the Taconic system, that is, the oldest limestone stratum of the system according to Emmons. They come from Canaan, New York, near the Massachusetts border, and several species have been determined by Prof. Dwight, notwithstanding the metamorphism of the rock. They include remains of Murchisonias, Pleurotomarias, Crinoids, Fenestellæe, a Trilobite, and probably some Brachiopods, showing that this limestone is not pre-Cambrian or Cambrian, but belongs probably to the Trenton or Lower Silurian age of the Eastern or Stockbridge limestone.-Preliminary report of S. W. Ford and W. B. Dwight upon the fossils obtained in 1885 from metamorphic limestones of the Taconic series of Prof. Emmons at Canaan, New York: A. Explanatory statement with reference to the palæontological investigations at Canaan, by W. B. Dwight. The authors are strongly inclined to the opinion that the limestones of Canaan, which have yielded these fossils, are of Trenton age.-On surface transmission of electrical discharges, by $\mathrm{H}$. S. Carhart. A practical bearing of the experiments here described and illustrated is that there is no sufficient scien. tific basis for making lightning conductors of large surface, and that large sectional area is essential to ample conductivity.-The minerals of Litchfield, Maine, by F. W. Clarke. The paper contains a careful study and analysis of the elæolite, cancrinite, sodalite, hydronephelite (new species), albite, and lepidomelane from the numerous boulders of an elæolite rock scattered over the district between Litchfield and West Gardiner, in Kennebec
County, Maine.-On the chemical behaviour of iron in the magnetic field, by Edward L. Nichols. A set of experiments with aquaregia, nitric acid, hydrochloric acid, and sulphuric acid is here described in illustration of the phenomenon that, when finely-divided iron is placed in a magnetic field of considerable intensity and exposed to the action of an acid, the chemical reaction differs in many respects from that which occurs under ordinary circumstances. The experiments are preliminary to a more complete investigation of the novel series of effects developed by them. The inculcation of scientific method by example, with an illustration drawn from the Quaternary geology of Utah, by G. K. Gilbert. This paper is a reprint of the Presidential Address read before the American Society of Naturalists at Boston, December 27,1885 . It discusses, not the results nor the subjectmatter of the several sciences with which naturalists are concerned, but their methods of investigation and their methods of teaching generally.-Nova Andromedæ, by Asaph Hall. The history of the discovery of the new star in Andromeda by Dr. Hartwig, of Dorpat, last August, its observation and gradual fading away, forms the subject of this paper.-On some new forms of the Dinocerata, hy W. B. Scott. What appears to be a missing link between the two sub-orders of Amblypoda (the Coryphodons of the Wahsatch Eocene and the Dinocerata of the Bridger) is here described under the name of Elachoceras. It was discovered by the Princeton Expedition of 1885 in the Bridger beds of Henry's Fork, Wyoming, and represents a genus allied to Uintatherium, without upper incisors, and having six molars of the Uintatherium type and large upper canine tusks, but without nasal protuberances, and having only rudiments of the maxillary and parietal protuberances. The supra-occipital is pierced by two large venous foramina placed one on each side of the median line. In the same locality, but at a somewhat higher level, was found a large Uintatherium skull, undoubtedly representing a new species (U. alticeps) of that genus.

The American Naturalist for April 1886 contains :-On the ancestry of Nasua, by Saml. Lockwood.-On the mechanism of soaring (illustrated), by J. Lancaster.-The Stone Age in Vermont (illustrated), by Geo. H. Perkins.-On Grosse's classification and structure of the Mallophaga (illustrated), by Geo. Macloskie.-On traces of a cyclone which passed over Western Indiana more than 300 years ago, by Jno. T. Campbell.-On the mounting of fossils (illustrated), by F. C. Hill.

\section{SOCIETIES AND ACADEMIES} LONDON

Royal Society, April I.- "On a New Form of Stereoscope." By A. Stroh.

Two optical lanterns are placed side by side, as for dissolving views. Two transparencies, photographed in the same manner as if intended for an ordinary stereoscope, are placed one in each lantern, and projected on a screen in such a position that they overlap each other as nearly as possible. The picture which is intended to be seen by the right eye may be placed in the righthand lantern, and the other in the left.

Supported by suitable framework, and in front of the two lenses of the lanterns, is a revolving disk, portions of which are cut away, so that during its revolutions it obscures the light of each lantern alternately, or, in other words, so that only one picture at a time is thrown on the screen. A continuous change from one picture to the other is thus obtained.

In the same framework, and in convenient positions for the observers, two pairs of eye-holes are provided, one pair on either side of the apparatus. Behind each pair is also a rotating disk, and these disks are connected by suitable wheel-work or drivingbands with the one previously mentioned, in such a way that the three disks rotate together, and at the same rate. The two lastnamed disks are also so cut that they will obstruct the view through the right and left eye-holes alternately.

Finally, the connection between the three disks has to be so arranged that the time of obscuring the view through the right eye-holes, or the left eye-holes, shall coincide with the time when the light is shut off from the right or left lens of the lanterns respectively.

It is obvious that by this arrangement an observer can only see the picture projected from the left lantern with the left eye, and the one from the right-hand lantern with the right eye.

The rotation of the disks must be of such a rate that the alternate flashes of the right and left pictures on the corresponding 